GOVERNING

yjOyOSIO 



\section{Laura Zanotti}

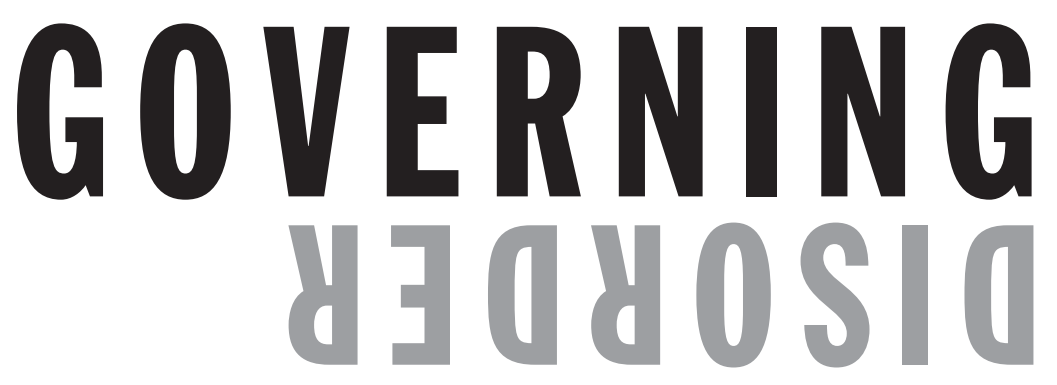

UN Peace Operations, International Security, and Democratization in the Post-Cold War Era

The Pennsylvania State University Press

University Park, Pennsylvania 
Zanotti, Laura.

Governing disorder : UN peace operations, international security, and democratization in the post-Cold War era / Laura Zanotti.

p. $\mathrm{cm}$.

Includes bibliographical references and index.

Summary: "Examines post-Cold War discourses about the use of power to promote international security. Uses case studies of United Nations interventions in Haiti and Croatia to highlight the dynamics at play in encounters between local societies and international peacekeepers"-Provided by publisher.

ISBN 978-0-271-03761-5 (cloth : alk. paper)

1. United Nations-Peacekeeping forces-Case studies.

2. Peace-building-Croatia-International cooperationCase studies.

3. Peace-building-Haiti-International cooperation-Case studies.

4. National security-Croatia-International cooperationCase studies.

5. National security-Haiti-International cooperationCase studies.

6. Power (Social sciences).

I. Title.

JZ5538.Z34 2011

$341.5^{\prime} 84-\mathrm{dc} 22$

2010048461

Copyright (๑) 2011 The Pennsylvania State University

All rights reserved

Printed in the United States of America

Published by The Pennsylvania State University Press,

University Park, PA 16802-1003

It is the policy of The Pennsylvania State University Press to use acid-free paper. Publications on uncoated stock satisfy the minimum requirements of American National Standard for Information Sciences-Permanence of Paper for Printed Library Material, ANSI Z39.48-1992.

This book is printed on Natures Natural, which contains 50\% post-consumer waste. 
A Giovanni.

Continua sempre a guardare con gli occhi nuovi di chi è da poco venuto al mondo. E non smettere di chiedere perché. 
